\title{
Removal of Six Estrogenic Endocrine-Disrupting Compounds (EDCs) from Municipal Wastewater Using Aluminum Electrocoagulation
}

\author{
Monica M. Cook ${ }^{1}$, Erin M. Symonds ${ }^{1}$, Bert Gerber ${ }^{2}$, Armando Hoare ${ }^{3}$, Edward S. Van Vleet ${ }^{1}$ \\ and Mya Breitbart ${ }^{1, *}$ \\ 1 College of Marine Science, University of South Florida, Saint Petersburg, FL 33701, USA; \\ mmion@mail.usf.edu (M.M.C.); esymonds@mail.usf.edu (E.M.S.); vanvleet@usf.edu (E.S.V.V.) \\ 2 Gerber Pumps International, Inc., Longwood, FL 32750, USA; bert@gerberpumps.com \\ 3 College of Arts \& Sciences, University of South Florida Saint Petersburg, Saint Petersburg, FL 33701, USA; \\ ahoare2@mail.usf.edu \\ * Correspondence: mya@usf.edu; Tel.: +1-727-553-3520 \\ Academic Editor: Jiangyong $\mathrm{Hu}$ \\ Received: 9 January 2016; Accepted: 28 March 2016; Published: 1 April 2016
}

\begin{abstract}
Conventional wastewater treatment plant (WWTP) processes are primarily designed to reduce the amount of organic matter, pathogens, and nutrients from the incoming influent. However, these processes are not as effective in reducing the concentrations of micropollutants, including endocrine-disrupting compounds (EDCs), which notoriously evade traditional wastewater treatment technologies and are found even in tertiary-treated effluent. For WWTPs practicing deep-well injection or surface-water discharge, EDCs in the treated effluent are discharged into groundwater or the aquatic environment where humans and wildlife may potentially suffer the effects of chemical exposure. In the current laboratory-scale study, we tested a bench-top electrocoagulation (EC) unit utilizing aluminum blades for the removal of six estrogenic EDCs [estrone (E1), 17 $\beta$-estradiol (E2), estriol (E3), 17 $\alpha$-ethinylestradiol (EE2), bisphenol-A (BPA), and nonylphenol (NP)]. Samples of municipal wastewater influent and tertiary-treated effluent were spiked with the six EDCs in order to test the removal efficiency of the EC unit. The mean concentration of each EDC component was statistically lower after EC treatment (removal range $=42 \%-98 \%$ ). To our knowledge, this is the first study to investigate aluminum electrocoagulation for removal of these specific EDCs, including nonylphenol (without the ethoxylate chain), as well as natural and synthetic estrogens.
\end{abstract}

Keywords: micropollutant; endocrine disruption; chemical contaminants; pharmaceutical; water treatment; wastewater; estrogen; electrocoagulation

\section{Introduction}

Micropollutants are chemical contaminants found in the aquatic environment in the $\mu \mathrm{g} / \mathrm{L}(\mathrm{ppb})$ or $\mathrm{ng} / \mathrm{L}(\mathrm{ppt})$ concentration range that are considered to be potential threats to environmental ecosystems [1,2]. Both domestic and industrial wastewaters contain micropollutants, which are not entirely removed by conventional wastewater treatment plant (WWTP) processes and are, therefore, continually discharged into the aquatic environment [3]. The origin of micropollutant contamination is predominantly anthropogenic and the aquatic environment becomes the final resting place for the majority of these chemical compounds [4,5].

Endocrine-disrupting compounds (EDCs) are an important class of micropollutants that are defined as exogenous chemicals, or mixtures of chemicals, that can interfere with any aspect of hormone action [6]. EDCs are a particularly troublesome subset of micropollutants, due to their diverse nature, persistence in the environment, and ability to cause metabolic and reproductive disturbances 
at very low concentrations. EDCs can enter the aquatic environment directly (e.g., through effluent discharge) or indirectly (e.g., storm-water runoff), but the major transport of EDCs to the aquatic environment is through treated and untreated municipal wastewater discharge to rivers, streams, and surface waters $[1,7,8]$. Potable water resources, including both surface water and groundwater, can become contaminated through surface-water discharge or deep-well injection of WWTP effluent [4]. Effects of EDCs on wildlife (invertebrates, fish, amphibians, reptiles, birds, and mammals) include: abnormal blood hormone levels, altered gonadal development (e.g., imposex and intersex), induction of vitellogenin gene and protein expression in juveniles and males, masculinization/feminization, hermaphroditism, and decreased fertility and fecundity [9-12].

Estrogenic EDCs specifically target estrogen signaling. These include natural steroidal estrogens, synthetic estrogens, and industrial compounds which mimic estrogen. $17 \beta$-estradiol (E2) is the primary natural estrogen and has the greatest potency. Estrone (E1), a metabolite of E2, is a slightly weaker estrogen. Estriol (E3), considered to be the final metabolite, is the weakest natural estrogen, with only $10 \%$ of E2's potency. $17 \alpha$-ethinylestradiol (EE2) is the synthetic steroidal estrogen component of contraceptives [13]. The overall estrogenicity of EE2 in effluent overshadows that of both E1 and E2 combined, due to its high estrogenic potency [14]. Bisphenol-A (BPA) is a monomer used in industry to produce lacquers, food-can liners, and thermal paper [15]. It has high water solubility and enters WWTPs through industrial discharges and leaching from BPA-based products. Nonylphenol (NP) is the persistent and estrogenic final product of the biodegradation of the non-ionic surfactant nonylphenol ethoxylate (NPEO) [16].

Conventional WWTP processes are designed primarily for the removal of organic matter, nitrogen, phosphorus, and pathogens; therefore, it is not surprising that the effluent from conventional WWTPs still contains EDCs at levels ranging from a few $\mathrm{ng} / \mathrm{L}$ to several $\mu \mathrm{g} / \mathrm{L}$, which are sufficient to cause endocrine disruption in some species [17]. The concentrations of EDCs in WWTP influent vary according to geographic location and population served, while the level of EDC removal during treatment varies according to the WWTP processes employed $[18,19]$. Monitoring studies have demonstrated that some wastewater treatment processes are more effective than others for reducing EDCs and ultimately a combination of approaches may be necessary to reduce this diverse class of micropollutants. This manuscript focuses solely on the potential of electrocoagulation (EC) for EDC removal in municipal wastewater, since the efficacy of various WWTP processes (e.g., biological treatment with activated sludge, activated carbon treatment, nanofiltration, reverse osmosis, ozonation, and advanced oxidative processes) for reducing EDC concentrations has been reviewed extensively [20-22].

Electrocoagulation technology reduces contaminant levels by passing an electrical current through water, which generates coagulant precursors by electrolytic oxidation of sacrificial anode material-usually aluminum or iron. During the EC process, amorphous insoluble polymeric metal hydroxides and oxides are formed, which adsorb pollutants (particulate and dissolved) during precipitation, making them easily separable [23,24] (Figure 1). The most widely used electrode materials, aluminum and iron, are both inexpensive and effective against a wide range of pollutants, including soluble organic pollutants $[25,26]$. Patented over a century ago, EC has a long history as a water treatment technology. However, EC was abandoned by the 1930s due to high operation costs, as well as the availablilty of inexpensive chemicals for chemical coagulation treatment [27]. Recent technical and design improvements, combined with a growing need for cost-effective water treatment processes, have led to a re-evaluation of EC technology [27]; however, to our knowledge no studies have tested the efficacy of EC with aluminum blades for reducing EDCs from municipal wastewater. This study therefore sought to determine the removal efficiency of a laboratory-scale electrocoagulation unit with respect to six estrogenic endocrine-disrupting compounds in WWTP influent and tertiary-treated effluent. 


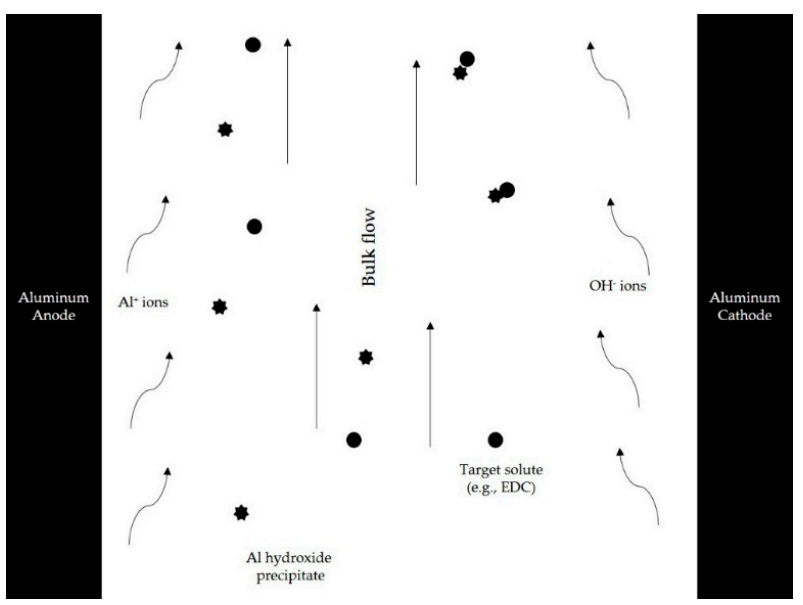

Figure 1. Representative schematic of water flow and interactions inside the reaction chamber. The two black vertical bars represent the electrodes where the power is attached, and the white in between them represents the sample solution flowing past the electrodes. Metal dissolution occurs at the anode which generates aluminum ions. Reduction reactions occur at the cathode which form hydroxide ions. The precipitation reaction occurs when the aluminum and hydroxide ions combine to form aluminum hydroxide (dark circles). The aluminum hydroxides form structures which adsorb contaminants (dark stars), enabling their removal.

\section{Materials and Methods}

\subsection{Electrocoagulation Unit}

The EC unit (Figure 2) is a 110-volt demonstration unit manufactured and supplied by Powell Water Systems, Inc. (Centennial, Colorado, USA; United States patent number 7211185 B2). The configuration used in this study has been previously examined for its ability to reduce concentrations of nutrients, personal care products, and microbial pathogens and indicators [28]. The power source is a 110-volt alternating current (AC) to direct current (DC) power converter (allowing direct line voltage to be converted from AC to DC) with voltage control. The pump is a Cole-Parmer ${ }^{\circledR}$ Masterflex Peristaltic Pump System (Vernon Hills, IL, USA) equipped with a 1/20-horsepower unidirectional motor and a separate single-turn speed control. The EC unit chamber $(35.6 \mathrm{~cm} \times 5.4 \mathrm{~cm} \times 2.5 \mathrm{~cm})$ is made of a non-conductive acrylic resin and has a total volume of $487.5 \mathrm{~mL}$. Nine aluminum reaction blades $(30.5 \mathrm{~cm} \times 2.5 \mathrm{~cm} \times 0.3 \mathrm{~cm})$ were arranged vertically inside the chamber with an electrode gap of $3.18 \mathrm{~mm}$. This vertical arrangement promotes a vertical flow of liquid through the chamber. The volume of one blade is $24.6 \mathrm{~cm}^{3}$ and the volume of all nine blades equals $221.2 \mathrm{~cm}^{3}$, leaving a residual chamber volume of $266.3 \mathrm{~mL}$. The EC unit was operated with a three-lead arrangement of electrical connections (power attached to blades 1, 5 and 9; Figure 3) which results in a configuration of two anodes and one cathode. The inflow tube measures $1.2 \mathrm{~m}$.
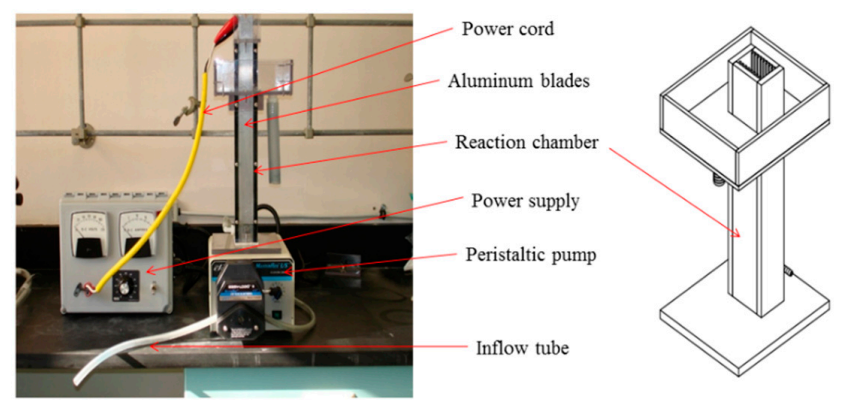

Figure 2. Schematic of laboratory-scale electrocoagulation unit. 


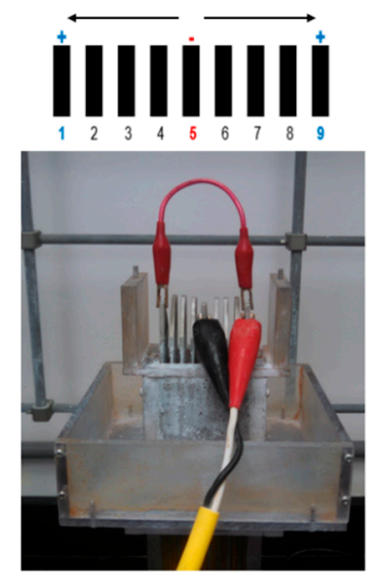

Figure 3. Diagram and close-up picture of the nine aluminum blades showing the electrical connections to blades 1,5 , and 9 . Anodes are indicated in blue by $(+)$, cathode is indicated in red by $(-)$, and arrows show the flow of electrons.

\subsection{Preliminary Tests and Optimization of Parameters}

The parameters used for this laboratory-scale study were chosen based upon a series of tests performed to evaluate EDC removal efficiency using different EC conditions and configurations (Supplementary Tables S1 and S2). The optimal parameters used for this study (Supplementary Table S3) were as follows: aluminum blades as the sacrificial electrodes, three-lead arrangement of electrical connections, sample retention time of $2 \mathrm{~min} / \mathrm{L}$ in the EC reaction chamber, volts held in the range of 85 to 98 , and amperes held in the range of 8.5 to 15.5. Inclusion of a precise cleaning step was important in the preliminary testing, as EDCs were found to "stick" to the walls of the unit and tubing. To ensure against cross-contamination between replicates, the EC unit was cleaned in between each run to remove any residual EDCs. The EC unit was cleaned by first removing the blades and rinsing the unit with tap water. The blades were scrubbed with steel wool in order to remove the build-up of the oxidizing layer. The scrubbed blades were then reset and the unit was flushed with $1 \mathrm{~L}$ ACS methanol to remove residual EDCs and $2 \mathrm{~L}$ deionized (DI) water to rinse the unit of residual methanol. Once the unit was cleaned, DI water laboratory blanks were passed through the unit (no power) to ensure that no EDCs remained in the unit. Polarity reversal of the electrodes was implemented between runs to help prevent the build-up of an oxidizing layer on the blade surface.

\subsection{Chemical Standards}

Analytical standards E1, E2, E3, EE2, BPA, NP, and $5 \alpha$-androstanol (internal standard) were purchased from Sigma-Aldrich (St. Louis, MO, USA). Methanol (HPLC grade and Certified ACS) and pyridine (Certified ACS) were purchased from Fisher Scientific (Pittsburg, PA, USA). $\mathrm{N}, \mathrm{O}$-bis(trimethylsilyl)trifluoroacetamide (BSTFA) with 1\% trimethylchlorosilane (TMCS) was purchased from Regis Technologies (Morton Grove, IL, USA). Ultrapure (DI) water was acquired from a US Filter PureLab Plus system.

\subsection{Wastewater}

Wastewater samples for the experiment were collected from South Cross Bayou Water Reclamation Facility, a tertiary treatment plant located in St. Petersburg, Florida (USA) which serves a population of approximately 260,000. The average wastewater flow per day is 20 million gallons (rated for 33 million gallons per day), and $85 \%$ of the wastewater is domestic in origin, while less than $15 \%$ is industrial in origin. South Cross Bayou's wastewater treatment processes follow the graphic in Figure 4. 


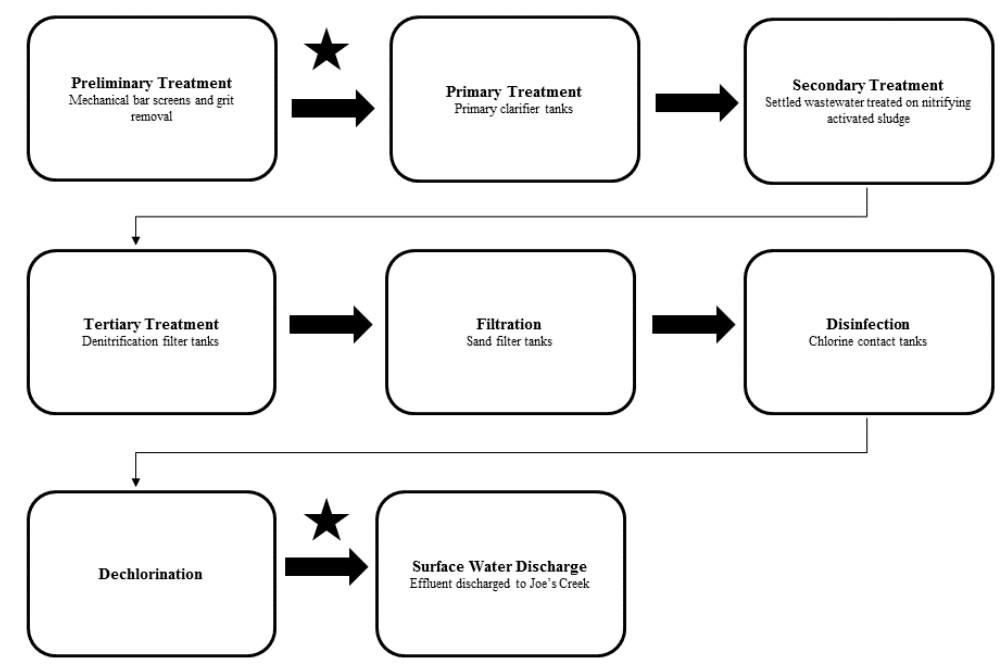

Figure 4. Illustration of the wastewater treatment processes at South Cross Bayou. Stars indicate the points of the raw influent and tertiary-treated effluent samples.

\subsection{Blanks}

Field blanks were taken at the sample site. Laboratory blanks (DI water spiked with internal standard) were extracted with each batch of samples. Gas chromatography-mass spectrometry (GCMS) instrument blanks (blank solvent injections) were performed every eight samples. All EDCs were undetectable in all the blank samples, including the DI water blanks that were run through the EC unit in between replicate runs, illustrating the effectiveness of the solvent cleaning step performed between runs.

\subsection{Experimental Design/Electrocoagulation Processing}

Both raw WWTP influent and tertiary-treated effluent were tested in this study in order to determine not only if the effectiveness of EC for reducing EDCs is matrix-dependent, but also to assess the possibility of using EC as a post-treatment addition to traditional WWTPs. Samples were collected the morning of the experiment in methanol-cleaned, $20 \mathrm{~L}$ high-density polyethylene carboys. Influent samples were taken at the headworks of the plant while effluent samples were collected after the dechlorination step. After sampling, the carboys were immediately transported to the lab and refrigerated at $4{ }^{\circ} \mathrm{C}$ until processing. In the lab, eight spiked-wastewater replicates (outlined below) were created. Half of the spiked-wastewater replicates $(n=4)$ went straight to analysis (pre-EC) and the other half $(n=4)$ were processed via electrocoagulation (post-EC). Due to the threat of BPA leaching from the Tygon tubing used in the experiment, BPA removal assays were conducted separately from the remaining EDCs.

Since background concentrations in the WWTP influent and effluent were too low to demonstrate significant removal potential by the EC unit, it was necessary to spike both with EDCs. High concentrations of EDC spikes were used to challenge the efficiency of the EC unit for removal. Stock standards were made up in methanol and, due to the low water solubility of steroids, were added to the pre-EC samples via methanol. Spikes were prepared for the four estrogens (estrone (E1), estradiol (E2), estriol (E3), ethinylestradiol (EE2)) at a concentration of $5 \mu$ g estrogen/250 $\mu \mathrm{L}$ methanol. Spikes were also prepared for the two industrial compounds (bisphenol-A (BPA) and nonylphenol (NP)) at a concentration of $20 \mu \mathrm{g}$ industrial compound/250 $\mu \mathrm{L}$ methanol. Due to their relatively higher concentrations in wastewater, NP and BPA were added at higher levels than the estrogens. Three liters of WWTP influent were spiked with the estrogens and nonylphenol after being filtered through a $1.5 \mu \mathrm{m}$ pore size, glass microfiber filter (Whatman 934-AH; Fisher Scientific, Pittsburgh, PA, USA). This resulted in a final concentration of $1.7 \mathrm{ppb}$ for the estrogens in wastewater and $6.7 \mathrm{ppb}$ 
for the industrial compounds in wastewater. Similarly, $3 \mathrm{~L}$ of WWTP effluent were spiked with the aforementioned EDCs.

In order to test the removal efficiency of the EC unit, $3 \mathrm{~L}$ of spiked WWTP influent $(n=4)$ and effluent $(n=4)$ were separately processed through the EC unit via a recirculation method, where the original sample was passed through the unit, discharged from the unit and then circulated back through the unit. The pump speed was set at eight which corresponded to a retention time of $2 \mathrm{~min} / \mathrm{L}$. The voltage fluctuated between 85 and 98 and the ampere readings fluctuated between 9 and 15.5 during EC treatment. Once the sample was collected from the EC unit, it was allowed to sit while coagulation began. After approximately 20 minutes, the EC-treated sample was filtered through two Whatman Grade 1 filters (pore size $11 \mu \mathrm{m}$ ) in order to separate the flocculent (sludge phase) from the treated water (aqueous phase). The final volume captured for analysis was $1 \mathrm{~L}$.

For the BPA experiment, $3 \mathrm{~L}$ of WWTP influent $(n=4)$ and effluent $(n=4)$ were spiked with BPA and processed through the EC unit via a one-time flow-through method where the sample would not retouch the Tygon inflow tube (manufactured with BPA). Since the temperature of the EC effluent could get as hot as $69{ }^{\circ} \mathrm{C}$, a one-time flow-through method was essential in order to prevent BPA leaching from the Tygon inflow tube. The pump speed was set at 2.2 which still corresponded to a retention time of $2 \mathrm{~min} / \mathrm{L}$. The voltage fluctuated between 94 and 98 and the ampere readings fluctuated between 8.5 and 14.5. The post-EC samples were collected as previously described after the flocculent was separated from the treated water.

\subsection{Solid Phase Extraction}

In order to determine the concentration of EDCs, the pre-EC and post-EC $1 \mathrm{~L}$ samples were processed via solid phase extraction (SPE) within 24 hours and subsequently analyzed via GCMS. An Evolute ABN (Acid, Base, Neutral) column $(6 \mathrm{~mL} / 200$ mg, Biotage; Charlotte, NC, USA) was conditioned with methanol and equilibrated with DI water. The sample was then loaded onto the column at a flow rate of $15 \mathrm{~mL} / \mathrm{min}$ using a large volume extraction tank (Biotage, USA) and an SPE vacuum pump. EDCs retained in the column matrix were eluted with $6 \mathrm{~mL}$ methanol. The eluate was spiked with $5 \mu \mathrm{g}$ internal standard and evaporated to dryness under a gentle stream of nitrogen. Recoveries of all compounds were documented and accounted for in the final quantification.

\subsection{Determination of EDC Concentrations}

Samples were derivatized to their trimethylsilyl ethers by adding $250 \mu \mathrm{L}$ of BSTFA $+1 \%$ TMCS and $250 \mu \mathrm{L}$ of pyridine, followed by heating in a $60{ }^{\circ} \mathrm{C}$ water bath for $40 \mathrm{~min}$ in order to drive the derivatization reaction to completion. Samples were then transferred to a $2 \mathrm{~mL}$ vial via low volume insert for analysis by GCMS. The GCMS system (Bruker; Fremont, CA, USA) consisted of a Varian 3800 gas chromatograph coupled with a Varian 320 mass spectrometer. The GCMS was equipped with a $30 \mathrm{~m} \times 0.25 \mathrm{~mm}$ (internal diameter) ZB-5MS (Phenomenex; Torrance, CA, USA) fused silica capillary column coated with a $5 \%$ phenyl arylene $/ 95 \%$ dimethylpolysiloxane stationary phase (film thickness $0.25 \mu \mathrm{m}$ ). Helium (high purity) was used as the carrier gas at a flow rate of $1 \mathrm{~mL} / \mathrm{min}$. The GC oven temperature was programmed to begin at $150{ }^{\circ} \mathrm{C}$ with an initial hold time of $2 \mathrm{~min}$, followed by a temperature ramp of $6^{\circ} \mathrm{C} / \mathrm{min}$ until reaching $310^{\circ} \mathrm{C}$. The final hold time was $6 \mathrm{~min}$ for a total run time of $35 \mathrm{~min}$. The MS was operated in selected ion monitoring (SIM) mode for quantitative analysis using electron impact (EI) ionization at 70 electron volts $(\mathrm{eV})$. The dwell time per atomic mass unit (amu) was 0.5 seconds, and the quantitative and confirmatory ion fragments are outlined in Table 1. Method detection limits (MDLs) were based on standard deviate protocol and were evaluated using GCMS at a signal-to-noise ratio between 5 and 10. Nine replicates were spiked near the detection limit (S/N between 5 and 10) and carried through the entire analytical procedure. Based upon the variability of the replicates, the MDL for each compound was calculated as the standard deviation multiplied by the $t$-value for nine observations (eight degrees of freedom; $t$-value $=2.896$ ). MDLs were in the range of 1 to $3 \mathrm{ng} / \mathrm{L}$ (Table 1). 
Table 1. Characteristics of estrogenic endocrine-disrupting compounds and internal standard.

\begin{tabular}{|c|c|c|c|c|c|c|}
\hline Compound & Type & $\begin{array}{l}\text { Retention Time } \\
\text { (min) }\end{array}$ & Quantitative Ion & $\begin{array}{l}\text { Confirmatory } \\
\text { Ion(s) }\end{array}$ & $\begin{array}{l}\text { Method Detection } \\
\text { Limit (ng/L) }\end{array}$ & Structure \\
\hline Estrone (E1) & $\begin{array}{l}\text { Natural } \\
\text { estrogen }\end{array}$ & 21.9 & 342 & 218,257 & 2 & \\
\hline $17 \beta$-Estradiol (E2) & $\begin{array}{c}\text { Principal } \\
\text { natural estrogen }\end{array}$ & 22.4 & 416 & 129,285 & 1 & \\
\hline $\begin{array}{c}17 \alpha \text {-Ethinylestradiol } \\
\text { (EE2) }\end{array}$ & $\begin{array}{l}\text { Synthetic } \\
\text { estrogen }\end{array}$ & 23.8 & 425 & 440 & 1 & \\
\hline Estriol (E3) & $\begin{array}{l}\text { Natural } \\
\text { estrogen }\end{array}$ & 24.8 & 504 & 386 & 3 & \\
\hline
\end{tabular}


Table 1. Cont.

\begin{tabular}{|c|c|c|c|c|c|c|}
\hline Compound & Type & $\begin{array}{c}\text { Retention Time } \\
\text { (min) }\end{array}$ & Quantitative Ion & $\begin{array}{l}\text { Confirmatory } \\
\text { Ion(s) }\end{array}$ & $\begin{array}{l}\text { Method Detection } \\
\text { Limit (ng/L) }\end{array}$ & Structure \\
\hline Bisphenol-A (BPA) & $\begin{array}{c}\text { Industrial } \\
\text { estrogen mimic }\end{array}$ & 16.2 & 357 & 358,372 & 1 & \\
\hline Nonylphenol (NP) & $\begin{array}{c}\text { Industrial } \\
\text { estrogen mimic }\end{array}$ & 11.8 & 179 & 180,292 & 2 & \\
\hline $5 \alpha$-androstanol & $\begin{array}{l}\text { Internal } \\
\text { standard }\end{array}$ & 18.0 & 333 & 258 & $\mathrm{~N} / \mathrm{A}$ & \\
\hline
\end{tabular}




\subsection{Statistical Analysis}

SAS version 9.4 (SAS Institute Inc.; Cary, NC, USA) was used for statistical analysis of data retrieved from GCMS analysis. All values are reported as mean \pm SD. MANOVA was run with four groups (raw influent not treated, raw influent EC-treated, effluent not treated, and effluent EC-treated) with the 6 quantitative variables (E1, E2, EE2, E3, BPA, and NP) using Pillai's Trace statistic. If the MANOVA results showed statistical significance, then post hoc testing was run between the raw influent groups (not treated and EC-treated) and between the effluent groups (not treated and EC-treated) for each EDC.

\section{Results and Discussion}

\subsection{Removal of EDCs from Spiked-WWTP Influent by EC}

The mean removal achieved for each of the six EDCs from spiked-WWTP raw influent samples is illustrated in Figures 5 and 6. The mean removal efficiency ranged from 56\% (estriol, E3) to 81\% (nonylphenol, NP). Furthermore, each EDC post-EC had a statistically lower mean concentration than pre-EC (Table 2) obtained from the post hoc test of the statistically significant MANOVA result. NP was removed to the greatest extent (81\% removal). Other studies $[29,30]$ have investigated the removal of nonylphenol ethoxylates (NPEOs), but to our knowledge this is the first study to test the removal of the estrogenic breakdown product, NP, by electrocoagulation.

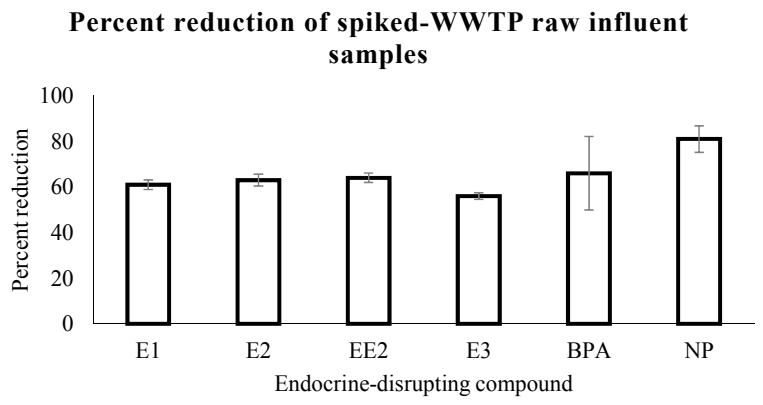

Figure 5. Percent reduction of endocrine-disrupting compounds from spiked-WWTP raw influent samples after electrocoagulation treatment. Error bars are mean $+/$ - standard deviation.

Spiked-WWTP raw influent

口Pre-EC 口Post-EC

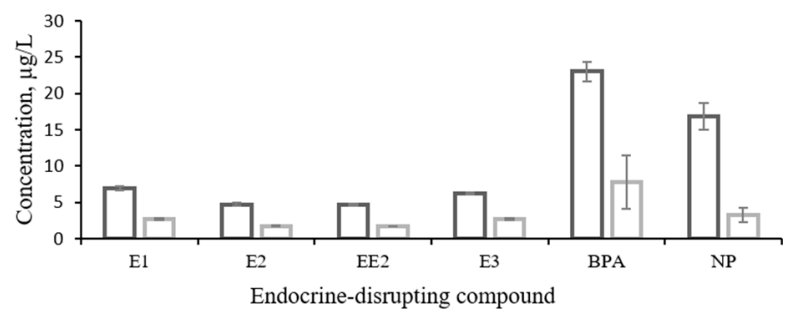

Figure 6. Mean concentrations plus or minus the standard deviation of six endocrine-disrupting compounds in spiked raw influent samples before and after electrocoagulation.

A significant finding was the $64 \%$ removal of EE2, which is important for two reasons: (1) this synthetic component of contraceptive products exhibits potent estrogenicity in the environment, with evidence of endocrine disruption at levels around $1 \mathrm{ng} / \mathrm{L}$ [10]; and (2) the removal of EE2 by other treatment processes has been historically problematic due to the recalcitrant nature of this compound [14]. 
Table 2. Percent removal of endocrine-disrupting compounds from spiked-WWTP raw influent samples.

\begin{tabular}{cccccc}
\hline EDC & $\begin{array}{c}\text { Mean Pre-EC } \\
\text { Conc } \pm \text { SD }(\mu \mathrm{g} / \mathrm{L})\end{array}$ & $\begin{array}{c}\text { Mean Post-EC } \\
\text { Conc } \pm \text { SD }(\mu \mathrm{g} / \mathrm{L})\end{array}$ & Test Statistic & $p$ Value & \% Removal \\
\hline E1 & $7 \pm 0.3$ & $3 \pm 0.1$ & $\mathrm{~F}=1194.45$ & $<0.0001$ & 61 \\
E2 & $5 \pm 0.2$ & $2 \pm 0.1$ & $\mathrm{~F}=954.56$ & $<0.0001$ & 63 \\
EE2 & $5 \pm 0.1$ & $2 \pm 0.1$ & $\mathrm{~F}=2079.79$ & $<0.0001$ & 64 \\
E3 & $6 \pm 0.2$ & $3 \pm 0.1$ & $\mathrm{~F}=1021.31$ & $<0.0001$ & 56 \\
BPA & $23 \pm 1$ & $8 \pm 4$ & $\mathrm{~F}=85.15$ & $<0.0001$ & 66 \\
NP & $17 \pm 2$ & $3 \pm 1$ & $\mathrm{~F}=133.28$ & $<0.0001$ & 81 \\
\hline
\end{tabular}

E3 was removed to a lesser extent (56\%) than any of the other compounds, which could be explained by its physico-chemical properties and its lower affinity for sorption onto organic solids. The octanol-water partition coefficient $\left(\mathrm{K}_{\mathrm{ow}}\right)$ describes the partitioning behavior of a compound between water and organic phases. The higher the $\mathrm{K}_{\mathrm{ow}}$, the more hydrophobic the compound and the more likely it is to be removed from solution. Most EDCs are hydrophobic compounds with similar $\log \mathrm{K}_{\mathrm{ow}}$ values (e.g., $\log \mathrm{K}_{\mathrm{ow}}$ values of 3.5-4). Since these hydrophobic compounds readily adsorb onto sludge solids, sorption plays an important role in their removal from the aqueous phase [31]. However E3, with its three hydroxyl groups, is only weakly hydrophobic $\left(\log \mathrm{K}_{\mathrm{ow}}=2.45-2.81\right)$ and is, therefore, less apt to bind to sludge [32]. Due to this, E3 likely does not have the same affinity for the flocculent produced during EC treatment. With more E3 in the aqueous phase (i.e., not bound to the EC flocculent), more of it withstands filtration and passes into the EC-treated water sample.

BPA concentrations were reduced by $66 \%$, which is important since BPA is one of the most highly produced chemicals in the world. BPA enters the WWTP at levels in the low ug/L range (concentration can be greatly increased if industrial discharges contribute to WWTP influent). Our findings support those of Govindaraj, et al. [33] who achieved 65\% removal of BPA from aqueous solutions using aluminum electrocoagulation. Compared with NP, BPA is a more polar compound which explains its lower levels of removal. BPA does not tend to adsorb to sludge particles/sediment as much as NP.

Estrone and estradiol had similar removal levels at $61 \%$ and $63 \%$, respectively. Of the natural estrogens, E2 has the greatest potency yet E1 still retains high estrogenicity. For this reason, it is important that both of these natural estrogens are reduced to a significant extent at the level of the WWTP. Since E1 retains estrogenicity and the amount of E1 discharged from WWTPs is more than ten times greater than that of E2, it has been suggested that E1 is the most important natural EDC [3].

\subsection{Removal of EDCs from Spiked-WWTP Tertiary-Treated Effluent by EC}

The mean removal achieved for each of the six EDCs from tertiary-treated effluent samples is illustrated in Figures 7 and 8. The removal efficiency ranged from $42 \%$ (BPA) to $98 \%$ (NP), and again each EDC post-EC had a statistically lower mean concentration than pre-EC (Table 3) obtained from the post hoc test of the statistically significant MANOVA result.

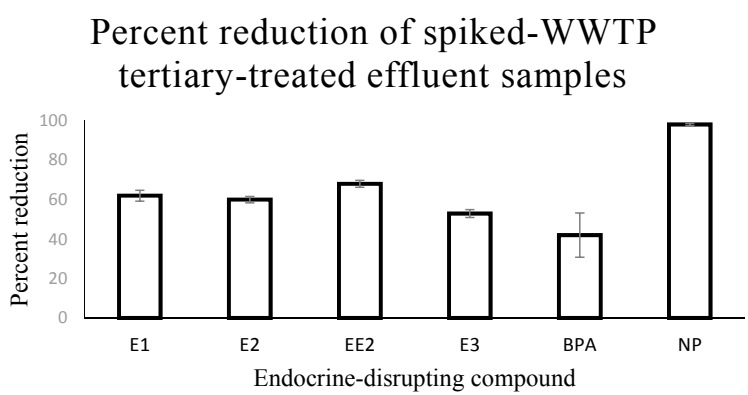

Figure 7. Percent reduction of endocrine-disrupting compounds from spiked-WWTP tertiary-treated effluent samples after electrocoagulation treatment. Error bars are mean +/- standard deviation. 


\section{Spiked-WWTP tertiary-treated effluent}

口Pre-EC 口Post-EC

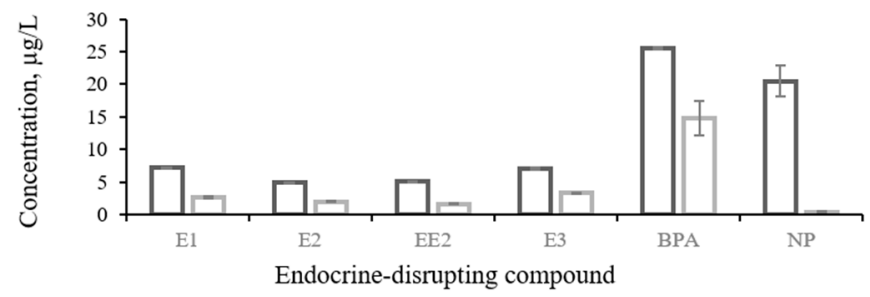

Figure 8. Mean concentrations plus or minus the standard deviation of six endocrine-disrupting compounds in spiked tertiary-treated effluent samples before and after electrocoagulation.

Table 3. Percent removal of endocrine-disrupting compounds from spiked-WWTP tertiary-treated effluent samples.

\begin{tabular}{cccccc}
\hline EDC & $\begin{array}{c}\text { Mean Pre-EC } \\
\text { Conc } \pm \text { SD }(\mu \mathrm{g} / \mathrm{L})\end{array}$ & $\begin{array}{c}\text { Mean Post-EC } \\
\text { Conc } \pm \text { SD }(\mu \mathrm{g} / \mathrm{L})\end{array}$ & Test Statistic & $p$ Value & \% Removal \\
\hline E1 & $7 \pm 0.1$ & $3 \pm 0.2$ & $\mathrm{~F}=1125.53$ & $<0.0001$ & 62 \\
E2 & $5 \pm 0.1$ & $2 \pm 0.1$ & $\mathrm{~F}=803.89$ & $<0.0001$ & 60 \\
EE2 & $5 \pm 0.1$ & $2 \pm 0.1$ & $\mathrm{~F}=2304.72$ & $<0.0001$ & 68 \\
E3 & $7 \pm 0.2$ & $3 \pm 0.1$ & $\mathrm{~F}=984.47$ & $<0.0001$ & 53 \\
BPA & $26 \pm 0.2$ & $15 \pm 3$ & $\mathrm{~F}=36.01$ & $<0.0001$ & 42 \\
NP & $21 \pm 2$ & $0.4 \pm 0.1$ & $\mathrm{~F}=250.89$ & $<0.0001$ & 98 \\
\hline
\end{tabular}

Higher levels of removal were achieved for NP $(98 \%)$ in the effluent than in the raw influent samples. However, even with $98 \%$ removal, the amount of NP in the final treated sample may still retain estrogenicity. This will be an important question in future testing of EC at environmentally-relevant concentrations. The amount of NP in our post-EC sample, $367 \mathrm{ng}$, may still be high enough to cause endocrine disruption due to the high initial spike. However, if $98 \%$ removal is still achieved at environmentally-relevant concentrations, it will be important to determine if the post-EC concentration is estrogenic or not. In vitro bioassays have the advantage of screening for estrogenicity without a priori knowledge of the pollutant present, and this will be a useful tool in future EC testing.

EE2 was removed to a high extent $(68 \%)$ which again is important considering the potent estrogenicity of this compound in the environment as well as its recalcitrant behavior concerning most treatment processes. Estriol was reduced by $53 \%$ which is comparable to the raw influent. A lower removal was seen with BPA $(42 \%)$ than in the raw influent samples. Estrone and estradiol were similarly removed (62\% and $60 \%$, respectively) as in the raw influent samples. Since the combination of E1 and E2 contribute largely to the estrogenicity of a sample, their removal is of considerable importance in water treatment processes.

\subsection{Implementation Considerations and Concluding Remarks}

A detailed comparison of the EDC removal results obtained using EC with typical removal levels achieved using other existing technologies has been presented in Cook et al. [34]. While it is clear that additional technologies are needed to reduce micropollutant concentrations, the decision to implement EC treatment requires a cost-benefit analysis, with the main costs of EC being energy consumption [35] and consumable blade materials. EC utilizes fairly simple equipment and can be easily integrated into existing WWTPs without extensive reorganization of the plant's structure and design. The lack of moving parts reduces the required maintenance [23], and the unit can be inserted into any point in the WWTP process, since the effectiveness of EC for reducing EDCs in this study did not depend on the matrix (water) type. For WWTPs that utilize tertiary treatments, like ozonation or filtration, EC could 
be incorporated as an additional pre-cleaning step before tertiary treatment. The effects of EC (e.g., reducing the amount of metal ions, heavy metals, colloids, oil wastes, dyes, suspended particles, etc.) would produce an effluent amenable to tertiary treatment and should reduce the fouling of these latter steps $[25,36]$. For WWTPs with no tertiary treatment, the EC process could be used to coagulate the raw sewage before going into the existing plant clarification unit. Not only would it reduce levels of chemical oxygen demand, turbidity and many contaminants [37], but it would also have the added benefit of EDC removal. EC can also be used to replace conventional chemical coagulation in plants where that technology is in use, since EC reduces the direct handling of corrosive chemicals and does not produce any secondary pollution caused by added chemical substances [35,37]. Furthermore, EC is a low-sludge producing technique, and the sludge formed tends to be readily settleable and easy to de-water [23].

Future testing should include environmentally-relevant concentrations in WWTP influent and effluent. Since these concentrations, especially for the natural and synthetic estrogens, are on the order of low ng/L, detection limits of analytical instruments used will need to be pushed to the $\mathrm{pg} / \mathrm{L}$ range. Bioassays will also be an important tool in future testing to determine the final estrogenicity of samples due to the fact that pollutants rarely occur as isolated compounds in environmental matrices, but rather in complex mixtures where pollutants can act synergistically, antagonistically, or additively. Finally, future research should continue to explore the potential synergy of combining EC with additional emerging treatment technologies. For example, a recent study demonstrated that combining electro-enzymatic catalysis with EC results in efficient removal of BPA from water [38].

\section{Conclusions}

In conclusion, the electrocoagulation of wastewater (WWTP raw influent and tertiary-treated effluent) spiked with six estrogenic EDCs was tested for efficiency of removal using a laboratory-scale unit. EC, with the optimal operating parameters determined in this study, enabled statistically significant removal of all EDCs in both WWTP raw influent (56\%-81\% removal) and tertiary-treated effluent (42\%-98\% removal). Although determining the mechanisms responsible for EDC removal is beyond the scope of this study, it is likely that these compounds were removed through sorption onto the amorphous aluminum hydroxide flocs followed by filtration. These flocs, termed "sweep flocs", have large surface areas which promote rapid adsorption of soluble organic compounds [39]. In this study, all samples were spiked with EDCs to challenge the EC instrument with removal of significant quantities of contaminants. Overall, this study demonstrated that aluminum EC can reduce EDC concentrations in municipal wastewater influent and effluent, a property that merits further exploration in anticipation of future regulations regarding EDC discharge into the environment.

Supplementary Materials: The following are available online at www.mdpi.com/2073-4441/8/4/128/s1. Table S1: Preliminary Testing, June 2012; Table S2: Preliminary Testing, November 2012; Table S3: Replicate Experiment for Verification of Optimal Parameters.

Acknowledgments: The authors wish to acknowledge Powell Water Systems, Inc. (Centennial, CO, USA) for funding this study; Albert McAfee for assistance with multiple wastewater sampling appointments; South Cross Bayou Water Reclamation Facility for their willingness to participate in and provide wastewater samples for this scientific endeavor; Ethan Goddard for GCMS technical assistance; Candice Bowman, Cedric Symonette, Alex Huynh, Rachel Harbeitner, Bethany Levenson, Shannon McQuaig, Karyna Rosario and Robert Ulrich for facilitating execution of experiments. Erin Symonds was funded by STAR Fellowship Assistance Agreement No. FP-91737601-3 from the U.S. Environmental Protection Agency (EPA). This work has not been formally reviewed by the U.S. EPA; therefore, the views expressed in this paper are solely those of the authors and any mention of products does not constitute recommendation for use.

Author Contributions: All authors conceived and designed the experiments; Monica M. Cook, Erin M. Symonds, Bert Gerber and Armando Hoare performed the experiments and analyzed the data; Monica M. Cook wrote the paper; Monica M. Cook, Erin M. Symonds, Bert Gerber, Armando Hoare, Edward S. Van Vleet and Mya Breitbart edited and approved the final manuscript.

Conflicts of Interest: The authors declare no conflict of interest. 


\section{Abbreviations}

The following abbreviations are used in this manuscript:

$\begin{array}{ll}\text { WWTP } & \text { Wastewater treatment plant } \\ \text { EDC } & \text { Endocrine-disrupting compound } \\ \text { EC } & \text { Electrocoagulation } \\ \text { E1 } & \text { estrone } \\ \text { E2 } & 17 \beta \text {-estradiol } \\ \text { E3 } & \text { estriol } \\ \text { EE2 } & 17 \text {-ethinylestradiol } \\ \text { BPA } & \text { bisphenol-A } \\ \text { NP } & \text { nonylphenol } \\ \text { NPEO } & \text { nonylphenol ethoxylate } \\ \text { BSTFA } & \text { N, O-bis(trimethylsilyl)trifluoroacetamide } \\ \text { DI } & \text { deionized } \\ \text { GCMS } & \text { gas chromatography-mass spectrometry } \\ \text { MDL } & \text { method detection limit } \\ \text { TMCS } & \text { trimethylchlorosilane } \\ \text { EI } & \text { (electron impact) }\end{array}$

\section{References}

1. Clara, M.; Strenn, B.; Gans, O.; Martinez, E.; Kreuzinger, N.; Kroiss, H. Removal of selected pharmaceuticals, fragrances and endocrine disrupting compounds in a membrane bioreactor and conventional wastewater treatment plants. Water Res. 2005, 39, 4797-4807. [CrossRef] [PubMed]

2. Virkutyte, J., Varma, R.S., Jegatheesan, V., Eds.; Treatment of Micropollutants in Water and Wastewater; IWA Publishing: London, UK, 2010; p. 483.

3. Auriol, M.; Filali-Meknassi, Y.; Tyagi, R.D.; Adams, C.D.; Surampalli, R.Y. Endocrine disrupting compounds removal from wastewater, a new challenge. Process Biochem. 2006, 41, 525-539. [CrossRef]

4. Mompelat, S.; Le Bot, B.; Thomas, O. Occurrence and fate of pharmaceutical products and by-products, from resource to drinking water. Environ. Int. 2009, 35, 803-814. [CrossRef] [PubMed]

5. Hester, R.E., Harrison, R.M., Eds.; Marine Pollution and Human Health; Royal Society of Chemistry: Cambridge, UK, 2011; p. 182.

6. Zoeller, R.T.; Brown, T.R.; Doan, L.L.; Gore, A.C.; Skakkebaek, N.E.; Soto, A.M.; Woodruff, T.J.; Vom Saal, F.S. Endocrine-disrupting chemicals and public health protection: A statement of principles from the endocrine society. Endocrinology 2012, 153, 4097-4110. [CrossRef] [PubMed]

7. Falconer, I.R.; Chapman, H.F.; Moore, M.R.; Ranmuthugala, G. Endocrine-disrupting compounds: A review of their challenge to sustainable and safe water supply and water reuse. Environ. Toxicol. 2006, 21, 181-191. [CrossRef] [PubMed]

8. Zhang, C.; Li, Y.; Wang, C.; Niu, L.; Cai, W. Occurrence of endocrine disrupting compounds in aqueous environment and their bacterial degradation: A review. Crit. Rev. Environ. Sci. Technol. 2015, 46, 1-59. [CrossRef]

9. Jobling, S.; Casey, D.; Rogers-Gray, T.; Oehlmann, J.; Schulte-Oehlmann, U.; Pawlowski, S.; Baunbeck, T.; Turner, A.P.; Tyler, C.R. Comparative responses of molluscs and fish to environmental estrogens and an estrogenic effluent. Aquat. Toxicol. 2004, 66, 207-222. [CrossRef] [PubMed]

10. Kidd, K.A.; Blanchfield, P.J.; Mills, K.H.; Palace, V.P.; Evans, R.E.; Lazorchak, J.M.; Flick, R.W. Collapse of a fish population after exposure to a synthetic estrogen. Proc. Natl. Acad. Sci. USA 2007, 104, 8897-8901. [CrossRef] [PubMed]

11. Janex-Habibi, M.-L.; Huyard, A.; Esperanza, M.; Bruchet, A. Reduction of endocrine disruptor emissions in the environment: The benefit of wastewater treatment. Water Res. 2009, 43, 1565-1576. [CrossRef] [PubMed]

12. Nadzialek, S.; Vanparys, C.; Van der Heiden, E.; Michaux, C.; Brose, F.; Scippo, M.-L.; De Coen, W.; Kestemont, P. Understanding the gap between the estrogenicity of an effluent and its real impact into the wild. Sci. Total Environ. 2010, 408, 812-821. [CrossRef] [PubMed] 
13. Spencer, A.L.; Bonnema, R.; McNamara, M.C. Helping women choose appropriate hormonal contraception: Update on risks, benefits, and indications. Am. J. Med. 2009, 122, 497-506. [CrossRef] [PubMed]

14. Cicek, N.; Londry, K.; Oleszkiewicz, J.A.; Wong, D.; Lee, Y. Removal of selected natural and synthetic estrogenic compounds in a canadian full-scale municipal wastewater treatment plant. Water Environ. Res. 2007, 79, 795-800. [CrossRef] [PubMed]

15. Danzl, E.; Sei, K.; Soda, S.; Ike, M.; Fujita, M. Biodegradation of bisphenol A, bisphenol F and bisphenol S in seawater. Int. J. Env. Res. Public Health 2009, 6, 1472-1484. [CrossRef] [PubMed]

16. Gultekin, I.; Ince, N.H. Synthetic endocrine disruptors in the environment and water remediation by advanced oxidation processes. J. Environ. Manag. 2007, 85, 816-832. [CrossRef] [PubMed]

17. Khanal, S.K.; Xie, B.; Thompson, M.L.; Sung, S.; Ong, S.K.; Van Leeuwent, J. Fate, transport, and biodegradation of natural estrogens in the environment and engineered systems. Environ. Sci. Technol. 2006, 40, 6537-6546. [CrossRef] [PubMed]

18. Fernandez, M.P.; Noguerol, T.-N.; Lacorte, S.; Buchanan, I.; Piña, B. Toxicity identification fractionation of environmental estrogens in waste water and sludge using gas and liquid chromatography coupled to mass spectrometry and recombinant yeast assay. Anal. Bioanal. Chem. 2009, 393, 957-968. [CrossRef] [PubMed]

19. Holmes, M.; Kumar, A.; Shareef, A.; Doan, H.; Stuetz, R.; Kookana, R. Fate of indicator endocrine disrupting chemicals in sewage during treatment and polishing for non-potable reuse. Water Sci. Technol. 2010, 62, 1416-1423. [CrossRef] [PubMed]

20. Luo, Y.; Guo, W.; Ngo, H.H.; Nghiem, L.D.; Hai, F.I.; Zhang, J.; Liang, S.; Wang, X.C. A review on the occurrence of micropollutants in the aquatic environment and their fate and removal during wastewater treatment. Sci. Total Environ. 2014, 473, 619-641. [CrossRef] [PubMed]

21. Basile, T.; Petrella, A.; Petrella, M.; Boghetich, G.; Petruzzelli, V.; Colasuonno, S.; Petruzzelli, D. Review of endocrine-disrupting-compound removal technologies in water and wastewater treatment plants: An EU perspective. Ind. Eng. Chem. Res. 2011, 50, 8389-8401. [CrossRef]

22. Tijani, J.O.; Fatoba, O.O.; Petrik, L.F. A review of pharmaceuticals and endocrine-disrupting compounds: Sources, effects, removal, and detections. Water Air Soil Pollut. 2013, 224, 1-29. [CrossRef]

23. Mollah, M.Y.A.; Schennach, R.; Parga, J.R.; Cocke, D.L. Electrocoagulation (EC)—Science and applications. J. Hazard. Mater. 2001, 84, 29-41. [CrossRef]

24. Rodriguez, J.; Stopic, S.; Krause, G.; Friedrich, B. Feasibility assessment of electrocoagulation towards a new sustainable wastewater treatment. Environ. Sci. Poll. Res. Int. 2007, 14, 477-482. [CrossRef]

25. Canizares, P.; Jimenez, C.; Martinez, F.; Saez, C.; Rodrigo, M.A. Study of the electrocoagulation process using aluminum and iron electrodes. Ind. Eng. Chem. Res. 2007, 46, 6189-6195. [CrossRef]

26. Gadd, A.; Ryan, D.; Kavanagh, J.; Beaurain, A.-L.; Luxem, S.; Barton, G. Electrocoagulation of fermentation wastewater by low carbon steel $(\mathrm{Fe})$ and 5005 aluminium $(\mathrm{Al})$ electrodes. J. Appl. Electrochem. 2010, 40, 1511-1517. [CrossRef]

27. Holt, P.K.; Barton, G.W.; Mitchell, C.A. The future for electrocoagulation as a localised water treatment technology. Chemosphere 2005, 59, 355-367. [CrossRef] [PubMed]

28. Symonds, E.; Cook, M.; McQuaig, S.; Ulrich, R.; Schenck, R.; Lukasik, J.; Van Vleet, E.; Breitbart, M. Reduction of nutrients, microbes, and personal care products in domestic wastewater by a benchtop electrocoagulation unit. Sci. Rep. 2015, 5, 9380. [CrossRef] [PubMed]

29. Ciorba, G.A.; Radovan, C.; Vlaicu, I.; Masu, S. Removal of nonylphenol ethoxylates by electrochemically-generated coagulants. J. Appl. Electrochem. 2002, 32, 561-567. [CrossRef]

30. Martins, A.F.; Wilde, M.L.; Vasconcelos, T.G.; Henriques, D.M. Nonylphenol polyethoxylate degradation by means of electrocoagulation and electrochemical fenton. Sep. Purif. Technol. 2006, 50, 249-255. [CrossRef]

31. Ivashechkin, P.; Corvini, P.F.; Dohmann, M. Behaviour of endocrine disrupting chemicals during the treatment of municipal sewage sludge. Water Sci. Technol. 2004, 50, 133-140. [PubMed]

32. Chang, S.; Waite, T.D.; Schäfer, A.I.; Fane, A.G. Adsorption of trace steroid estrogens to hydrophobic hollow fibre membranes. Desalination 2002, 146, 381-386. [CrossRef]

33. Govindaraj, M.; Sudhir, A.; Sukumar, C.; Hariprakash, B.; Pattabhi, S. Treatment of endocrine disrupting chemical from aqueous solution by electrocoagulation. Sep. Sci. Technol. 2012, 48, 295-302. [CrossRef]

34. Cook, M. Endocrine-Disrupting Compounds: Measurement in Tampa Bay, Removal From Sewage and Development of an Estrogen Receptor Model. Ph.D. Thesis, University of South Florida, Tampa, FL, USA, 2015. 
35. Akbal, F.; Camc1, S. Copper, chromium and nickel removal from metal plating wastewater by electrocoagulation. Desalination 2011, 269, 214-222. [CrossRef]

36. Murthy, Z.V.P.; Parmar, S. Removal of strontium by electrocoagulation using stainless steel and aluminum electrodes. Desalination 2011, 282, 63-67. [CrossRef]

37. Gamage, N.P.; Chellam, S. Aluminum electrocoagulation pretreatment reduces fouling during surface water microfiltration. J. Membr. Sci. 2011, 379, 97-105. [CrossRef]

38. Zhao, H.; Zhang, D.; Du, P.; Li, H.; Liu, C.; Li, Y.; Cao, H.; Crittenden, J.C.; Huang, Q. A combination of electro-enzymatic catalysis and electrocoagulation for the removal of endocrine disrupting chemicals from water. J. Hazard. Mater. 2015, 297, 269-277. [CrossRef] [PubMed]

39. Attour, A.; Touati, M.; Tlili, M.; Ben Amor, M.; Lapicque, F.; Leclerc, J.P. Influence of operating parameters on phosphate removal from water by electrocoagulation using aluminum electrodes. Sep. Purif. Technol. 2014, 123, 124-129. [CrossRef]

(C) 2016 by the authors; licensee MDPI, Basel, Switzerland. This article is an open access article distributed under the terms and conditions of the Creative Commons by Attribution (CC-BY) license (http:/ / creativecommons.org/licenses/by/4.0/). 